\title{
Postdigital Feminism and Cultural Visual Regimes: Covid-19 at Women's Only University in the Gulf
}

\section{Zoe Hurley ${ }^{1}$}

Published online: 19 May 2020

(C) Springer Nature Switzerland AG 2020

Keywords Postdigital feminism - Visual regimes · Hyper-visuality · Media literacies · Selfpresentations · Micropractices · Online learning $\cdot$ Empowerment $\cdot$ Arab women · Gulf

...the visual is impure and culture is shifting, thereby creating fruitful tensions.

(Gruber and Haugbolle 2013)

\section{Covid-19 At Women's Only University in the Gulf}

Transitioning to teaching online at a women's only university in the Gulf during the Covid-19 makes me, like millions of other university teachers globally, increasingly reflective. With the world in crisis, there is renewed focus on theoretical tensions within the postdigital condition, and my interest is in unique female insights and their positioning in postdigital theory and practice (Deepwell 2020). How does women's learning intersect across physical spaces, digital infrastructures and learning ecologies? Or is it perhaps somewhere else, across all of these, as well as in-between (Pyyhtinen and Suoranta 2020)? How do these online practices affect women from different cultures? What precisely does it mean to be postdigital if you are female (Jandrić et al. 2019)? How can a postdigital critical pedagogy be informed by feelings of love, kindness and compassion for learning, learners and one another, while hopefully keeping women employed (Petrilli 2017)? These questions were pertinent prior to Covid-19, they are particularly poignant now, and they are imperative for future development of postdigital feminist theory and practice.

Zoe Hurley

Zoe.hurley@zu.ac.ae

1 Zayed University, Dubai, United Arab Emirates 
I discuss these issues with my $\mathrm{PhD}$ supervisor Nataša Lacković, an international woman-academic working at a UK university, during our long chats online. These conversations are interrupted by intermittent Wi-Fi, the needs of my teenage children, and a pervasive sense that I am somehow under-achieving at everything including my teaching, research and certainly provision of the domestic sphere. I even worry about the inherent value system within this ordering of worries. Yet these conversations about our feelings, of both unease and excitement, evoke a surreal sense of the uncanny (Jandrić and Kuzmanić 2020). These are messy and unpredictable times, but Nataša's quirky take on the situation is strangely comforting.

Online meetings with my university teaching colleagues involve vertiginous highs, lows and an eerie sense of business as usual. Despite the lack of preparation, classes must be taught, exams must be taken, and appearances must be upheld (Goffman 1956). Our collective uncertainty, exhaustion, fear and inadequacies are not voiced, since they are the deeply buried secrets and silences of the neoliberal university (Gill 2009). My work during the Covid-19 lockdown started with preparing for online meetings by wearing red lipstick, downscaled to beige, and now I wear no lipstick at all. It's a struggle to get dressed some days. I rarely brush my hair. While I teach online, grade assignments and procrastinate, I imagine my own kids are baking, playing music, working out and getting much more sleep. Unsurprisingly, they appreciate aspects of their unexpected deschooling (Illich 1970).

But the reality involves my 14-year-old daughter going viral on Pinterest (without either of us knowing what this means) through her collages of 'wellness' and influencer lifestyle boards; my 18-year-old son taking inspiration from Japanese anime characters (Cobb 2018) and dying his hair pink (which looks really cool); and my 16-year-old son's online gaming lasts for hours, since he no longer has to sit for his GCSE exams. Each of my children, in their own way, is engaging in 'Dopamine Escape' (Means 2020: 269). Through intense connections to the online sphere, they occupy postdigital bubbles of comfort in times of trouble (Lacković 2020). But I am distracted and shift focus.

\section{Hyper-Contradictions, Hybridity and Paradoxes}

Nataša, my supervisor and now friend, reminds me that some universities possess an already established online learning infrastructure, making the new order easier to roll out for some, but not all. What happens in the end, like always, will depend on context. Online education is more than choosing a suitable learning management system or having adequate Wi-Fi connectivity. Technological affordances are also about emerging macro, meso and micro postdigital practices, which are socio-material, situated and contextual. Visual affordances such as video conferencing or profile pictures also depend on particular kinds of literacies that are acquired through processes of learning, and these processes are contingent with particular cultural ways of seeing and being seen. Visual culture is 'both globalizing and localizing quite often simultaneously' (Gruber and Haugbolle 2013: x). Working at a women's only university in the Gulf makes me wonder about the micropractices of my students and pragmatic choices facing them on a daily basis. How do they juggle family life and financial restraints, while justifying to themselves that it is worth working towards a university degree, in the time of lockdown, and with such an uncertain future ahead? 
Struggles and dilemmas of these women are largely invisible in mainstream scholarship. They are reluctant to complete online surveys since they, like many, suffer from survey fatigue. Yet, my (now online) students appear uncomfortable with the uncanny mode of 'business as usual' during the coronavirus crisis.

Gulf-Arab women across the region are currently often the first members of their families to enrol in higher education and $70 \%$ of students at public universities are women (Davidson 2012). This privilege and opportunity follow an edict of "empowerment.' In the United Arab Emirates for example, 'The National Strategy for Empowerment of Emirati Women' mandates 'how women are empowered through services and facilities in the areas of education, health, jobs and more' (The United Arab Emirates' Government portal 2015). Similarly, Qatar's Commission on the Status of Women and the Qatar National Vision 2030 prioritizes the empowerment of women (Ministry of Foreign Affairs 2017). These policies legislating the empowerment of women are linked to the region's attempts to become knowledge economies yet are embedded within a number of contradictions and challenges. Resulting data trails paint inspiring yet somewhat unconvincing pictures of participation. In terms of immediate practices, the coronavirus crisis exacerbates the fault lines, or less obvious issues, facing Gulf-Arab women learners and teachers in Muslim majority countries. While these issues may not seem apparent on the surface, since most women have access to the devices and Wi-Fi necessary for online learning, there are deeper systemic issues.

For example, the gendered taboo surrounding Arab women showing their faces via (online) media raises additional issues concerning postdigital visual learning regimes. In Memoirs from the Women's Prison, Egyptian feminist activist Nawal El Saadawi (1983: 29) observes controversies surrounding Muslim women's facial presentations. 'Two eyeholes' of a female inmate interrogate her. A disembodied voice asks, 'Isn't a woman's face a blemish upon her, a shameful private part to be covered?' However, choosing whether or not to cover your face or hair is often a cultural or personal decision rather than a strictly religious choice (Killian 2019). Conversely, while Islam has been perceived as a faith that avoids iconic images, there has been a staple of Islamic representational arts and manuscripts decorated with figural and animal imagery from the thirteenth century onward (Gruber 2015).

Following their shift online, universities are now making an uninvited entry into Gulf-Arab women's highly private domestic sphere. Requirements for students and teachers' self-presentation during online course delivery contribute to the pervasive sense of Covid-related anxiety. Gulf-Arab students are reticent about the use of webcams and concerned about showing their faces online (Sanderson 2020). Teachers have had little time to prepare for the emergency online course delivery and do not necessarily have the skill set of media professionals, content creators, or instructional designers. In view of the challenges, universities in the United Arab Emirates have guaranteed that students are exempt from being dismissed due to failing courses during this turbulent period (Ahmed 2020).

Gulf-Arab women's responses are not monolithic. Some of them accept online learning in their stride, while others, including students with special needs, face increasing challenges. In Kuwait, some women are increasingly fearful of the rising graduate unemployment rate which currently sits at over 40\% (Al Bawaba 2019). Consequently, the coronavirus crisis has triggered an escalation of hostility towards the nation's migrant population that makes approximately $80 \%$ of the workforce (Al 
Sherbini 2020). In Qatar's universities, women professors from Middle East and North Africa occupy key positions accompanied by financial security, safety and status which is not necessarily available in their home countries such as Syria, Egypt, Jordan, Palestine, Morocco and Tunisia (Dalacoura 2019).

In Saudi Arabia, the Covid-19 lockdown curfew was partially lifted to celebrate the beginning of Ramadan. We can only hope that this will ease challenges facing women students and professors, some of whom have limited status and access to support being widows, divorced, or unmarried. At the same time, thousands of migrant women from the Global South, workers and teachers in the Gulf's private education sector, have been placed on leave, offered redundancy and face an uncertain (employment) future (Hubbard 2020). Many of these women educators, who are leaving the region on recent repatriation flights, are the sole breadwinners for their extended families. Left without income, these women have little to return to and may not necessarily be welcomed back in their countries of origin. For women from the Global South, the coronavirus crisis in the Gulf-Arab region is the context of hyper-contradictions, hybridity and paradoxesa true postdigital rupture (Jandrić et al. 2019).

\section{Postdigital Feminism and Cultural Visual Regimes}

Visual challenges in the Covid-19 pandemic raise questions central to postdigital feminist theorizing: Who can be seen, heard and recognized as signifying? Who sees, listens and interprets? Answers to these questions are not transparent. They occur in terms of interstices and intersections of power relations and economics. Consequently, having agency, to see, know and be, occurs within visual regimes that are underpinned by globalization, platform capitalism and gender inequalities within the postdigital condition.

Gulf-Arab women do not see themselves as victims and are taking steps to demonstrate that. For example, it has become customary for women to write the permission to study, work or travel abroad into their marriage contracts. A number of Gulf-Arab women are social media influencers, or microcelebrities, enjoying prolific followings without necessarily ever showing their faces online (Hurley 2019a). Nevertheless, while women make up over $60 \%$ of university graduates, they experience double the amount of unemployment (Culbertson 2016). Such paradoxes play out visually at multiple levels. For example, traditional customs of wearing the abaya and hijab continue as religious and ethnic symbols, yet these practices have become nuanced and experimental with design, fabrics, cut and ornamentation. While often avoiding overt displays of the face or body online, Gulf-Arab women's self-presentations represent intricate narratives concerning the fragmentation of 'self' and the multiple roles that social actors are asked to perform during the current global crisis and the regimes of postdigital hypervisuality, whereby each sign embeds histories, systemic relations and cultural values.

Technological solutionism seems to promise that learning can be downloaded almost like an app and in a business model similar to Amazon and Uber (Means 2018). GulfArab women are responding in distinct ways to what Katy Deepwell (2020) calls the 'plug and play' models of education that are mediated via generic platform architectures. Their responses to fill-in boxes, choices of colour schemes and visual identity templates are situated within specific socio-material contexts (Hurley 2019a). Reflexive responses of Gulf-Arab women are significant because they indicate that postdigital visual regimes, 
although increasingly standardized, are not necessarily taken up in universal ways. Furthermore, we need to understand more about hybrid visual micropractices and postdigital self-presentations across the merging offline/online learning contexts which are both local and global. These are significant issues and reveal the extent to which postdigital visual regimes are not monolithic. Although it is generally accepted that everyone lives a global life, what might be backgrounded is the extent to which these lives are also vastly differentiated through being local (Giddens 1999).

Differences, inequalities and anxieties are also exacerbated semiotically in the postdigital realm via images since interpretation occurs at the nexus of social, emotional, economic and technological practices and meanings (Lacković 2020; Hurley $2019 b$ ). These issues raise questions about postdigital assemblages, which involve entanglements of human agency within matter, materialism, technologies and hypervisualities (Barad 2007; Haraway 1987). These assemblages also involve varying modes of technological corporate and state surveillance as well as women's own gendered self-surveillance. A postdigital perspective could help to reveal how visual regimes bundle ideologies of traditionalism, gender inequalities, postcolonialism and late capitalism in contradictory matrices.

In relation to the Gulf-Arab region emerges a tier of questions concerning feminist theorizing within the postdigital condition. These questions occur at macro and meso levels to consider policy concerning learners and online learning practices, yet they also require a focus on women's intersectional micropractices. Detailed insights into hybrid responses to visual learning regimes may not become apparent at global levels, nor through conceiving of women's empowerment in exclusively economic and/or legislative terms. Although these are important starting points, top-down theorizing involves a tendency to limit insights into learners and educators' varying practices and differences. We need to develop more nuanced ways of seeing to consider the literal blind spots surrounding women's learning and hyper-inequalities in the Global South.

\section{References}

Ahmed, A. (2020). COVID-19: University students in the UAE exempted from academic warnings and dismissals. Gulf News, 21 April. https:/gulfnews.com/uae/covid-19-university-students-in-the-uaeexempted-from-academic-warnings-and-dismissals-1.71090887. Accessed 4 May 2020.

Al Bawaba. (2019). Over 40 percent of Kuwaiti university graduates unemployed. 1 April. https://www. albawaba.com/business/over-40-percent-kuwaiti-university-graduates-unemployed-1274510. Accessed 4 May 2020.

Al Sherbini, R. (2020). Kuwaiti coronavirus patient spits at nurse, doctor says. Gulf News, 11 March. https://gulfnews.com/world/gulf/kuwait/kuwaiti-coronavirus-patient-spits-at-nurse-doctor-says1.70306273. Accessed 4 May 2020.

Barad, K. (2007). Meeting the Universe Halfway. Durham, NC: Duke University Press.

Cobb, K. (2018). Stream it or skip it: 'BAKI', Netflix's fighting anime about death row inmates. Decider, 18 December. https://decider.com/2018/12/18/baki-on-netflix-stream-it-or-skip-it/. Accessed 4 May 2020.

Culbertson, S. (2016). The fires of spring: A post-Arab spring journey through the turbulent new Middle East. New York: St Martin's Press.

Dalacoura, K. (2019). Women and gender in the Middle East and North Africa: Mapping the field and addressing policy dilemmas at the Post-2011 Juncture. Barcelona: MENARA http://eprints.lse.ac. uk/100742/1/Dalacoura_Women_and_Gender.pdf. Accessed 4 May 2020. 
Davidson, C. (2012). Higher education in the Gulf: A historical background. In C. Davidson \& P. Smith (Eds.), Higher education in the Gulf states: Shaping economies, politics and culture. London: SOAS Middle East Issues.

Deepwell, K. (2020). Postdigital education, feminism, women. Postdigital Science and Education, 2(2), 248253. https://doi.org/10.1007/s42438-019-00096-1.

El Saadawi, N. (1983). Memoirs from the women's prison. London: Zed Books.

Giddens, A. (1999). Modernity and self-identity. In A. Jaworski \& N. Coupland (Eds.), The Discourse Reader. London and New York: Routledge.

Gill, R. (2009). Breaking the silence: The hidden injuries of neo-liberal academia. In R. Ryan-Flood \& R. Gill (Eds.), Secrecy and silence in the research process: Feminist reflections. London: Routledge.

Goffman, E. (1956). The presentation of self in everyday life. London: Penguin.

Gruber, C. (2015). The Koran does not forbid images of the prophet. Newsweek, 1 September. https:/www. newsweek.com/koran-does-not-forbid-images-prophet-298298. Accessed 4 May 2020.

Gruber, C., \& Haugbolle, S. (2013). Visual culture in the modern Middle East. Bloomington: Indiana University Press.

Haraway, D. (1987). A manifesto for cyborgs: Science, technology, and socialist feminism in the 1980s. Australian Feminist Studies, 2(4), 1-42. https://doi.org/10.1080/08164649.1987.9961538.

Hubbard, B. (2020). Coronavirus fears terrify and impoverish migrants in the Persian Gulf. New York Times, 13 April. https:/www.nytimes.com/2020/04/13/world/middleeast/persian-gulf-migrants-coronavirus. html. Accessed 4 May 2020.

Hurley, Z. (2019a). Why I no longer believe social media is cool. Social Media + Society, 5(3). https://doi. org/10.1177/056305119849495.

Hurley, Z. (2019b). Imagined affordances of Instagram and the fantastical authenticity of Gulf-Arab social media influencers. Social Media + Society, 5(1). https://doi.org/10.1177/2056305118819241.

Illich, I. (1970). Deschooling society. London and New York: Marion Boyars.

Jandrić, P., \& Kuzmanić, A. (2020). Uncanny. Postdigital Science and Education, 2(2), 239-244. https://doi. org/10.1007/s42438-020-00108-5.

Jandrić, P., Ryberg, T., Knox, J., Lacković, N., Hayes, S., Suoranta, J., Smith, M., Steketee, A., Peters, M. A., McLaren, P., Ford, D. R., Asher, G., McGregor, C., Stewart, G., Williamson, B., \& Gibbons, A. (2019). Postdigital dialogue. Postdigital Science and Education, 1(1), 163-189. https://doi.org/10.1007/s42438018-0011-x.

Kilian, C. (2019). Why do Muslim women wear a hijab?. The Conversation, 15 January. https://theconversation.com/why-do-muslim-women-wear-a-hijab-109717. Accessed 4 May 2020.

Lacković, N. (2020). Thinking with digital images in the post-truth era: A method in critical media literacy. Postdigital Science and Education, 2(2), 442-462. https://doi.org/10.1007/s42438-019-00099-y.

Means, A. (2018). Learning to save the future. New York: Routledge.

Means, A. (2020). Adapting the Xanax generation: Meditations on catastrophic precarity and postdigital melancholia. Postdigital Science and Education, 2(2), 267-274. https://doi.org/10.1007/s42438-01900070-x.

Ministry of Foreign Affairs (2017). Qatar stresses commitment to women's empowerment. https://mofa.gov. qa/en/all-mofa-news/details/2017/03/16/qatar-stresses-commitment-to-women's-empowerment. Accessed 4 May 2020.

Petrilli, S. (2017). Challenges to living together: Transculturalism, migration, exploitation for a semioethics of human relations. Milan: Mimesis International.

Pyyhtinen, O., \& Suoranta, J. (2020). Lecture as an event in postdigital education: A dyadic teaching diary. Postdigital Science and Education, 2(2), 348-364. https://doi.org/10.1007/s42438-020-00104-9.

Sanderson, D. (2020). UAE students speak out against webcam policy for online exams. The National, 13 April. https:/www.thenational.ae/uae/education/uae-students-speak-out-against-webcam-policy-foronline-exams-1.1005549. Accessed 4 May 2020.

The United Arab Emirates' Government portal (2015). Women - The official portal of the UAE Government. https://u.ae/en/information-and-services/social-affairs/women. Accessed 4 May 2020. 